\title{
Komentarze
}

\section{Ojczyzna i obczyzna: Irlandia, Polska i Inni}

Declan Kiberd

TEKSTY DRUGIE 2016, NR 3, S. 154-164

DOI $10.18318 /$ td. $2016.3-9$

O statnie dziesięciolecie XX wieku i pierwsze XXI to lata migracji do Irlandii. Sporo osób przybyło tu, by zamieszkać. Polacy ściągali tu tak tłumnie że w wielu miasteczkach średniej wielkości miał rację bytu wyspecjalizowany sklep polski - jak również polskie salony fryzjerskie. Te miejsca bez wątpienia funkcjonowały także jako ośrodki kulturalne. Wysokonakładowa gazeta „Evening Herald" raz w tygodniu publikowała wkładkę po polsku. Za sprawą kwitnącego budownictwa do pracy na budowie przyjeżdżało wielu mężczyzn z Polski, a Polki chętnie były zatrudniane do pracy w sklepach i biurach. Analogie historyczne między obydwoma krajami były całkiem realne - historia inwazji i cierpienia, buntowniczej wiary katolickiej i najeżonego trudnościami dostosowywania się do warunków nowoczesności. Wielu młodym Polakom Irlandia wydawała się przyjazna i atrakcyjna. Dawała dostęp do szerszego świata anglojęzycznego. Była równocześnie bliska i odległa - wystarczająco daleka od „domu”, żeby wydawać się autentycznie innym miejscem, a jednak dostatecznie bliska, by nie wywoływać przykrego wrażenia obcości. Szyblie wprowadzenie
Declan Kiberd - prof., wykłada na Filologii Irlandzkiej w University of Notre Dame, USA. Był kierownikiem Katedry Literatury Anglo-irlandzkiej w University College Dublin i dyrektorem Abbey Theatre oraz Yeats Summer School. Wykładał goścınnie w ponad 35 krajach i opublikował wiele ksiązek, w tym Inventing /reland (1995), Irish Classics (2000), The lrish Writer and the World (2005). Ulysses and Us (2009) Kontakt: dkiberd@ nd.edu 
tanich lotów przez dostosowujące się do wymagań rynkowych linie lotnicze wzmocniło to poczucie łączności - także coraz więcej Irlandczylków korzystało z moźliwości takich podróży, by zaznajomić się z Polską. Z czasem wielu polskich migrantów zawierało małżeństwa w swoim gronie i decydowało się na osiedlenie w Irlandii; sporo Polek wychodziło za Irlandczyków; również - choć w mniejszym stopniu - Polacy żenili się z Irlandkami lub kobietami mieszkającymi w Irlandii. Znacząca liczba Irlandczyków dochodziła do wniosku, że Polki są w miły sposób dużo bardziej tradycjonalne w swoich obyczajach niż postfeministyczne Irlandki; jednakże Irlandki czasami musiały uznać, że bardziej staroświeckie postawy Polaków wprawiają je w zakłopotanie. Wiele z tych doświadczeń wzruszająco, choć nieco niezręcznie przedstawił Daniel Żuchowski w zbiorze opowiadań The New Dubliners [Nowi Dublińczycy] (2014).

Pokaźna liczba polskich robotników przybyłych do Dublina przeniosła się do Londynu podczas prac budowlanych poprzedzających Igrzyska Olimpijskie w tym mieście. Ich wspomnienia, ustne i spisane, pod wieloma względami przypominają takie książki jak Dialann Deoraí [Dziennik emigracji] Dónala MacAmhlaigha, pochodzący z połowy XX wieku zapis życia robotników budowlanych w środkowej Anglii, opublikowany w końcu pod tytułem An Irish Navvy [Irlandzki robotnik]. Większość z nich, jak dotąd, w przeciwieństwie do książki Żuchowskiego, powstaje w języku ojczystym, jako rodzaj tajnego szyfru, który umoźliwia dokonanie swego rodzaju ,studium antropologicznego à rebours" w odniesieniu do obyczajów kraju przyjmującego.

Jak w Anglii w połowie ubiegłego stulecia, opowiadane przeżycia są już same w sobie złożone, a dodatkowo komplikuje je równoczesna imigracja przedstawicieli innych narodów. W dzisiejszej Irlandii największą grupę imigrantów stanowią Rosjanie. Część z nich jest niezwykle bogata, natomiast inni przyjmują niskopłatne prace. Niektórzy znajdują zatrudnienie w świetnie prosperujących, supernowoczesnych gałęziach przemysłu w Dublinie, Galway i innych miastach, innym zaś (jak wielu przybyszom z Polski) przypadają prace zupełnie niewspółmierne $\mathrm{z}$ ich kwalifikacjami akademickimi czy zawodowymi. Istnieje także spora grupa Chińczyków, wystarczająco liczna i wpływowa, by obchody Chińskiego Nowego Roku stały się ważnym wydarzeniem kulturalnym w Dublinie. A jeszcze nie powiedzieliśmy o wyczuwalnej obecności Nigeryjczyków (wielu z nich powiększyło szeregi wyznawców Kościołów ewangelickich), Brazylijczyków, a także robotników zWłoch i innych krajów europejskich, w których występuje wysokie bezrobocie wśród młodych. Wielu z tych przybyszów przyjechało, by uczyć się języka 
angielskiego, ale postanowiło zostać na stałe. Wzbogacili Irlandię, która, po kryzysie ekonomicznym z lat 2007-2008, straciła wielu młodych obywateli, preferujących emigrację. Jest oczywiste, że wielu przyjezdnych chętnie pracuje za skromne wynagrodzenie w zawodach, które przynajmniej część wyjeżdzających Irlandczyków uznaje za nieatrakcyjne. Ale exodus młodych Irlandczyków jest prawdopodobnie równie złożony, jak sto lat temu, kiedy J.M. Synge pisał, że motywy emigracji nie zawsze są natury ekonomicznej jego zdaniem ludzie wyjeżdżają wskutek zwątpienia we wspólną przyszłość i często jako element reakcji łańcuchowej wywołanej emigracją przyjaciół, którzy wywędrowali wcześniej. Są powody, by twierdzić, że ta emigracja, choć pozornie irracjonalna po okresie dominacji „celtyckiego tygrysa”, stanowiła powrót do irlandzkich wzorców dominujących od dwustu lat. Frank O'Connor dobrze to podsumował, mówiąc, że wielu z tych, którzy wyjechali, uczyniło to nie z powodu nienawiści do imperialnego prawa czy tłamszących praktyk religijnych, lecz po prostu dlatego, że ich zdaniem życie, jakie ich tu czekało, było nudne i mierne. Wydaje się, że motywy wielu przybywających do Irlandii w ostatnim dwudziestoleciu były często zadziwiająco podobne. Przecież nie wszyscy są migrantami ekonomicznymi.

Od pewnego czasu „The Irish Times” prowadzi stronę internetową zatytułowaną "Generation Emigration" [Emigracja pokolenia]. W świecie sieci cyfrowych i łatwych podróży irlandzkość (jak i polskość) stała się wirtualna. Można nawet mieć poczucie, że słowo „emigracja” ma charakter hiperboliczny w czasach, gdy niektórzy określają się mianem „dojeżdżających”. Jest także oczywiście prawdą, że wielu z tych, którzy wyjechali w latach trudności gospodarczych, zapewne żywiło uświęconą tradycją nadzieję powrotu, ale jednak nigdy jej nie zrealizowało. Bardzo wysokie podatki, zwłaszcza w czasach, gdy podatnicy musieli łożyć na ratunek finansowy dla bankierów, są często przytaczane przez młodych emigrantów jako powód ich trwającej nieobecności w kraju - ale należałoby także zauważyć, że niektórzy Irlandczycy zatrudnieni za granicą są w stanie żyć na pewnym poziomie w Irlandii (a często mają tu dom lub mieszkanie). Zjawisko emigracji na pół etatu jest bardziej rozpowszechnione, niż się przypuszcza, podobnie jak fenomen hipermobilności z jednego miejsca do drugiego. Odnosi się to zapewne także do Polaków, Rosjan, Włochów i wielu innych grup. Wielu wykorzystuje miasta, takie jak Londyn czy Dublin, jako przystanki czy bazy wypadowe do dalszej emigracji - do Azji, Australii czy Ameryki Północnej.

Jeśli Irlandia w ostatnim dziesięcioleciu XX wieku stała się najbardziej zglobalizowaną gospodarką w Europie Zachodniej (choć jak dokładnie 
mierzy się taką rzecz?), to szeroki świat również nieco bardziej się zirlandyzował. Obecnie za granicą żyje i pisze zapewne więcej zawodowych pisarzy irlandzkich niż w jakimkolwiek momencie dziejów kultury - a należałoby do tego dodać także wielu pozostających w ojczyźnie (gdyż ci, którzy mieszkają w Irlandii, nie muszą już ponosić finansowych skutków cenzury i mogą zarabiać dzięki szerokiej publiczności za granicą). Lata 9o. XX wieku były dekadą, w której bycie Irlandczykiem stało się sexy, gdyż postmodernistyczne puby i przedstawienia Riverdance' skłoniły wielu do identyfikowania się ze swoim „wewnętrznym Paddym".

Nie zawsze był to wysublimowany proces, ponieważ często w kręgach międzynarodowych uznanie znajdowały bardziej uproszczone formy irlandzkości (tę samą uwagę wygłaszano o polskiej operze mydlanej Londyń$c z y c y)$. Być moźe kultura globalna rozbija tradycyjne wspólnoty, ale sponsorzy wciąż pragną kolorytu lokalnego - dlatego Prochy Angeli (Angela's Ashes) ${ }^{3}$ okazały się wielkim sukcesem, dowodząc, że Irlandia jest rozpaczliwie interesująca i interesująco rozpaczliwa, bardziej niż kiedykolwiek. Silniej modulowane pisarstwo Johna McGaherna nigdy nie miało takiego zasięgu jak utwory Franka McCourta. Gdy McCourt przejaskrawiał realia życia w Irlandii, by uczynić je bardziej interesującymi, McGahern był zdania, że życie Irlandczyków już samo w sobie jest tak ekstremalne, iż każdy poważny artysta musi nieco pomniejszyć problemy, by stały się wiarygodne. Jego amerykańscy wydawcy zareagowali nerwowo. Ostatnie (i największe) dzieło McGaherna, That They May Face the Rising Sun [By mogli zobaczyć wschodzące słońce], ukazało się w Stanach pod tytułem zmienionym na By the Lake [Nad jeziorem], żeby czytelnicy nie pomyśleli, że chodzi o przewodnik po Japonii.

Nawet w szczytowym okresie odrodzenia literatury irlandzkiej (Irish Literary Revival) na przełomie XIX i XX wieku świat zewnętrzny nadal pozostawał ważny - Paryż, Londyn i Nowy Jork to miasta, w których Irlandia była

1 Widowisko teatralne oparte na tradycyjnej muzyce irlandzkiej i tańcu. Od 1995 roku zostało wystawione $w$ ponad 450 miejscach na świecie, gromadząc przeszło 25 milionów widzów (wszystkie przypisy pochodzą od tłumacza).

2 Paddy (zdrobnienie od Patrick) - potoczne określenie Irlandczyka.

3 Książka wspomnieniowa Franka McCourta (1996), opisująca jego dzieciństwo i wczesny wiek dojrzały w irlandzkim Limerick oraz w nowojorskim Brooklynie; w 1997 roku wyróżniono ją nagrodą Pulitzera w kategorii „biografia lub autobiografia”. Pierwsze polskie wydanie ukazało się pod tytułem Popiółiżar. 
na nowo odkrywana przez emigranckich intelektualistów stykających się z innymi narodowościami. To zjawisko (jak to określił Benedict Anderson) wywołało efekt negatywu fotograficznego, bieli na czerni, który to negatyw te zamorskie elity następnie zmieniły na pozytyw w ojczystym kraju przez lata walki politycznej i kulturalnej. Jednakże państwo, które powstało w wyniku tych starań, często pozbawiało intelektualistów szansy zarobienia na życie - można było przyjąć posadę nauczyciela albo wyjechać (McGahern zaliczył i jedno, i drugie). Ci, którzy wyjechali, od czasu do czasu powracali, by przypomnieć sobie (jak mawiał Frank O'Connor), jakim strasznym miejscem stała sięich ojczyzna. Zapewne podobne opowieści o Polsce, Włoszech, Rosji i innych państwach piszą teraz emigranci z tych krajów. Cenzurowanie książek w Irlandii zelżało dopiero w latach 7o. XX wieku - w odróżnieniu od cenzury radzieckiej, mającej charakter polityczny i idącej od góry, irlandzka cenzura była oddolna, a jej motywacja często miała podłoże religijne (jeśli jakiś obywatel miał zastrzeżenia do danego utworu, mógł złożyć formalną skargę w Komisji Cenzury; niekiedy jedna skarga wystarczała do zakazania danej pozycji).

Mimo wysiłków osób związanych z Irish Revival, takich jak Yeats i jego następcy, aż do lat 70. i 80. XX wieku powstało bardzo niewiele rodzimych wydawnictw. Z drugiej jednak strony był to okres, kiedy styl młodszych autorów stawał się zdecydowanie międzynarodowy. Tradycyjne sztuki wystawiane w Abbey Theatre były traktowane jako papka dla turystów przez autorów współtworzących książki o tytułach w rodzaju Yeats nie żyje! czy Już nie Paddy. Wewnętrzną debatę dobrze wyraża wymiana zdań między dwoma wielkimi Johnami współczesnej powieści, Banville’em i McGahernem. - Chcę otworzyć okno na Europę - stwierdził Banville, który najwyraźniej studiował Piotra Wielkiego, pisząc wspaniałą trylogię o Koperniku, Keplerze i Newtonie. "- Tak - spontanicznie zripostował McGahern - i pewnie myślisz, że ja cały czas staram się zatrzasnąć to okno".

Ironia losu sprawia, że dziś możemy czytać trylogię Banville'a o naukowcach z czasów odrodzenia jak ukryte odniesienie do elementów konfliktu szalejącego wtedy w Irlandii Północnej, a także nawiązanie do starań o powiększenie udziału przedmiotów ścisłych i technicznych w szkolnych programach republiki irlandzkiej. Kiedyś zapytałem Banville'a, jak udało mu się tak bezbłędnie odtworzyć świat czarownic, alchemików i zaklęć. Odpowiedział: „- Z łatwością. Dorastałem w Wexford w latach pięćdziesiątych". - Ironia polega też na tym, że chociaż McGahern zaszył się w północnej części hrabstwa Leitrim - które, jak zauważył Denis Donoghue, nigdy nie było terenem ostrej 
rywalizacji literackiej - udało mu się zawrzeć na najgłębszym poziomie swej sztuki metody i tematy Flauberta, Prousta i Tołstoja.

Gdy w latach 90. rozpoczęła się oficjalna "globalizacja”, linie podziału w pisarstwie irlandzkim stały się bardzo wyraźne. Nawet w okresie, kiedy do Dublina ściągali ludzie z zagranicy, pisarze tacy jak Colm Toibin, Colm McCann czy Joseph O'Neill umieszczali akcję swoich powieści w Nowym Jorku, w Berlinie czy nawet w Ameryce Środkowej. A jednak każdy z nich, gdy juź doczekał się artykułu w „New York Timesie”, zostawał zrenacjonalizowany szybciej niż banki - a przynajmniej tak szybko, jak stało się to udziałem „irlandzkiego poety, W.B. Yeatsa" na łamach prasy londyńskiej i nowojorskiej w latach 30 . Yeats zauważył z pewnym znużeniem, że każdy irlandzki pisarz ma wybór - wyrażać swój kraj albo go wykorzystywać. Im więcej pisarzy jednak odmawiało przyłączenia się do kręgów irlandzkości, tym więcej ukazywało się artykułów wykrywających utajoną tematykę irlandzką w książkach, które pozornie wydawały się zupełnie nieirlandzkie.

Można było oczekiwać, że nowe, skomplikowane metody narracji uchwycą tę hybrydyczność i złożoność - przykłady tego pojawiały się w dziełach Seamusa Heaneya, Medbh McGuckian i poetów piszących po irlandzku, którzy niejako z definicji są juź wielokulturowi. Interesujące jest też to, że wśród osób uzyskujących najwyższe oceny podczas egzaminów maturalnych z irlandzkiego znajdują się uczniowie z polskich czy wietnamskich rodzin, pozbawieni wszelkich kompleksów przy opanowywaniu nowego języka. Najlepszym przykładem udanej hybrydyzacji może być sztuka Briana Friela Tańce w Ballybeg (Dancing at Lughnasa), która dzięki prezentacji dwóch wątków rozwijających się w różnym tempie wspaniale rozwiązuje techniczny problem przedstawienia kwestii „nierównego rozwoju”. Dramat Friela rejestruje wpływ teologii wyzwolenia i doświadczeń misjonarzy w Afryce na życie w zwykłej irlandzkiej parafii.

Jeśli jednak chodzi o powieść - gatunek, po którym można by się spodziewać najbardziej wnikliwej eksploracji irlandzkiego spotkania z Innym - to traktuje ona takie tematy z wielką nieśmiałością. Większość młodych powieściopisarzy, zapewne po prostu z przyczyn technicznych, zrezygnowała z tradycyjnych prób panoramicznego opisania całego społeczeństwa (choć to społeczeństwo jest wciąż dość mało liczne) i woli koncentrować się na tej czy innej podgrupie - studentach ostatniego roku w college'u, pracownikach restauracji, członkach zespołu rockowego itd. Jeden z najlepszych tworzących obecnie pisarzy, Keith Ridgway, podsumowat tę kwestię, nadając jednej ze swoich książek tytuł The Parts [Części]. To tak, jakby powieściopisarze dziś 
decydowali się robić to, co według Franka O'Connora robią twórcy opowiadań, przedstawiając „ukryte grupy”, osadzone w konkretnych miejscach w Dalkey, Coolock ${ }^{4}$ czy w środkowej Irlandii. W obrębie Dublina - z rzadkimi wyjątkami, jak np. Eggshells [Skorupki] Catriony Lally - żadna z powieści nie podejmuje panoramicznej wizji w stylu "The Wandering Rocks", a co dopiero kompleksowego portretu społeczeństwa, jak było w przypadku Strumpet City [Miasto ladacznic] nieżyjącego już Jamesa Plunketta.

Ci autorzy, którzy podejmują próby udramatyzowania spotkania z przybyszami, traktują ich zawsze jako „Nowych Irlandczyków”, rzadko zwracając uwagę na to, co ze sobą przynoszą. Imigrantowi najczęściej funduje się błyskawiczny kurs irlandystyki, a czytelnik może się zastanawiać, komu takie seminaria mają służyć. Wydawcom w Londynie i Nowym Jorku wciąż na próżno szukającym tej cholernej, wymykającej się im irlandzkości? Czy samym autorom, dorastającym może w klimacie rewizjonizmu, który tak bardzo zredukował treści narodowe, że teraz muszą z wdzięcznością chwytać się postaci przybysza jako pretekstu, by móc samemu zapoznać się z utraconą własną tradycją? Jest tak, jak gdyby współczesna powieść irlandzka często istniała po to, by wprowadzać w życie nowe statuty z Kilkenny ${ }^{6}$, czyniąc świeżo przybyłego „bardziej irlandzkim od samych Irlandczyków”7. Polscy ekspedienci są uważani za zasymilowanych kulturowo, kiedy dochodzą do momentu, w którym potrafią w rozmowie z klientem użyć wyrażenia "You're grand"s.

Julia Kristeva w książce Strangers to Ourselves [Obcy dla nas samych] stwierdza, że znajdujemy obcego w innych po to, by odkryć skryte, niewytłumaczone części samego siebie. Zauważa, że w takich krajach jak Francja, przyjmujących wielu imigrantów, partie prawicowe wiecznie martwią się o kulturę narodową, którą w idealnych (ich zdaniem) warunkach przyswoją sobie przybysze, natomiast partie lewicowe zwracają większą uwagę na te elementy kulturowe, jakie nowi przynoszą ze sobą. Naturalnie nowoczesność funkcjonuje

4 Dzielnice Dublina.

5 Tytuł dziesiątego rozdziału Ulissesa Joycéa.

6 Legislacja z 1366 roku mająca na celu ograniczenie wynarodowienia zdobywców, zakazująca Anglikom w Irlandii m.in. małżeństw z ludnością irlandzką i nakazująca im używania wyłącznie języka angielskiego.

7 "More Irish than the Irish themselves", zwrot używany wh historiografii irlandzkiej do opisania zjawiska asymilacji kulturowej w Irlandii pod rządami Normanów w późnym średniowieczu.

8 W irlandzkim angielskim zwrot ten oznacza „świetnie" albo „nie ma sprawy”. 
najlepiej, kiedy oba typy kultury są traktowane na tym samym poziomie przez wszystkie partie; wtedy jest nadzieja na coś nowego, połączenie, prawdziwą hybrydyczność.

Coś podobnego wydarzyło się we wcześniejszych latach panowania „celtyckiego tygrysa", do roku 2002. W tym świetlanym okresie sukcesu ekonomicznego świadczono prawdziwe usługi, produkowano dobrą żywność i wytwarzano wspaniałe urządzenia. Ale sukces ten nie szedł w parze, jak tego oczekiwali twórcy pierwotnego Irish Revival, z rozwojem kultury i polityki, lecz następował całkowicie niezależnie od nich. W miarę jak nieproduktywni "konsultanci" mieli coraz więcej do powiedzenia, ludzie zaczęli mieć wrażenie, że żyją w obrębie gospodarki, a nie w konkretnym kraju w grupie konsumentów, a nie w państwie narodowym. A jednak te świetne lata przed 2002 rokiem przyniosły prawdziwy postęp, m.in. w postaci wielokulturowej Irlandii pełnej imigrantów okazujących autentyczną ciekawość wobec irlandzkich tradycji oraz słuszną dumę z tradycji, które przynieśli ze sobą. Nadzieję budziły przykłady łączenia „ojczystego” z „obcym”, jakie moźna było znaleźć wszędzie - od powieści po filmy, od musicali po kuchnię.

Jedna z imigrantek z tamtych lat, Zeljka Doljanin, stwierdziła w swojej pracy doktorskiej napisanej w University College w Dublinie, że po roku 2002 było mniej fuzji, a w ogóle nie było myślenia o innych. Wielu z tych, którzy przybyli w szczytowej fazie boomu ekonomicznego po tym roku, zostało zwabionych przez wizję szybkich pieniędzy i wygodnego życia - byli o wiele mniej pewni wartości kulturowych, które ze sobą przynosili, i o wiele mniej ciekawi tej kultury, którą napotykali. Być może było coraz trudniej, nawet poważnie myślącym osobom, zrozumieć, czym naprawdę wtedy była „Irlandia”. Rząd zalany funduszami założył ponad siedemset agencji, które miały uciszyć tę czy inną podgrupę. Wiele z tych agencji stanowiło dość szlachetne próby ochrony tej czy innej mniejszości, ale w miarę ich rozwoju pojęcie wspólnej kultury czy wspólnoty społecznej zastępowała niekończąca się atomizacja. A i sami Irlandczycy byli pod wielkim wrażeniem wizji łatwej gotówki sławny pomnik królika przed centralą Allied Irish Bank został żartobliwie ochrzczony „The Quick Buck”. Ludzie, jak głosiła zgodna z modą gładka i nieprzemyślana diagnoza, „stracili panowanie nad sobą", czego rezultaty można było dostrzec na chodnikach Temple Bar ${ }^{10} \mathrm{w}$ każdy piątkowy czy sobotni

9 Gra słów - buck to zarówno królik، jak i dolar, a quick buck to "szybka forsa”.

10 Dzielnica Dublina, centrum kulturalne znane także z wielu nocnych lokali. 
wieczór. Żaden przywódca polityczny nie próbował wyartykułować wizji narodowej, takiej, jaką w swoich krajach starali się stworzyć Barack Obama czy François Hollande - język „patriotyzmu” został zdyskredytowany przez bomby IRA i przez antynacjonalistycznych komentatorów. Nawet ci przybysze, którzy starali się zrozumieć tożsamość Irlandczyków, często okazywali się bezradni wobec niemożności czy nawet niechęci większości ludzi do jej wyjaśnienia.

Dr Doljanin opracowała jeszcze bardziej radykalną analizę. W 2002 roku nie było już w obiegu banknotów z wizerunkami pisarzy (Yeatsa, Joyce'a, Douglasa Hyde'a itd.); zastąpiły je nijakie euromosty i budynki, które od początku miały wygląd „współczesnego gotyku” à la Łubianka. Irlandczycy utracili wyraźne poczucie tożsamości, a to utrudniło im kontakty z Innymi. Fakt, że niektórzy historycy odrzucali element kolonialny w przeszłości Irlandii, stanowił dla części Irlandczyków przeszkodę, by wczuć się w problemy polityczne, które skłoniły wielu z przybyszów do opuszczenia swojego kraju. Stąd wzięły się te osobliwie introwertyczne, zawiłe, spazmatyczne powieści, które rzekomo - ale nie naprawdę - zajmują się imigrantami, takimi jak sama dr Doljanin.

Żeby znaleźć relacje spotkań kultur, czytelnik powinien sięgać raczej po powieści klasyczne, a nie współczesne. Podróże Guliwera zajmują się właśnie wpływem migracji na zdefamiliaryzowanie terminów „dom" i „obczyzna” - a także wyczerpaniem, wewnętrzną pustką, a nawet mizantropią, które mogą być skutkiem zbyt wielu wymuszonych przystosowań. Castle Rackrent [Zamczysko Rackrent] ${ }^{\text {"1 }}$ wielokrotnie przypomina, jak osobliwie Irlandia musi wyglądać w oczach świeżo przybyłego, który ma się osiedlić w wiejskiej społeczności - antycypując Ulissesa Joyce'a w prezentacji przepełnionej niepokojem reakcji na Żydów. Trylogia Samuela Becketta, napisana po francusku, a potem przełożona na angielski, trafnie ujmuje doświadczenie uznawania wszystkiego za dziwne. Wszyscy ci autorzy byli synami monokulturowej Irlandii, a jednak - lub może właśnie DLATEGO - potrafili eksplorować inność.

W ostatnim semestrze w University College w Dublinie, kiedy czytałem Ulissesa z grupą studentów (złożoną po połowie z rodowitych Irlandczyków i obcokrajowców), zadałem im pewne pytanie. Jeżeli o pierwszej w nocy w Temple Bar spotkają jakiegoś trzydziestoośmiolatka wyglądającego na obcokrajowca i ten człowiek zaprosi ich do swojej kuchni, to czy pójdą z nim?

11 Powieść Marii Edgeworth (1800) krytykująca irlandzkich ziemian z XVIII wieku. 
„W życiu” - brzmiała jednogłośna odpowiedź. To nasza strata, ich zresztą też. Był czas, kiedy ludzie w Irlandii potrafili dobrze sobie radzić z własną obcością i z obcością innych. Miasto było strefą, w której ciągle napotykało się Innych, jak to robią Bloom i Stephen w książce Joyce'a. Podobnie było też na wsi - jeśli pojechało się na rowerze dziesięć mil od domu, to było się praktycznie w obcym miejscu, gdzie sposób chodzenia, mówienia czy hodowania kwiatów wydawał się całkiem odmienny. A teraz jest wiele przedmieść, centrów handlowych czy grodzonych osiedli, zaprojektowanych po to, by chronić ludzi przed przypadkowymi spotkaniami, które dają życie klasycznym opowiadaniom. Gdy coraz więcej ludzi jeździ po świecie, w tę i z powrotem, niezwyciężony prowincjalizm wydaje się brać górę. Na znaczeniu zyskuje ciasny nacjonalizm, będący odpowiedzią na niepewność ekonomiczną, lecz także na przymusowy internacjonalizm końca XX wieku, proponujący niewiele ponad nieprzemyślany konsumpcjonizm. A szerzej zakrojony projekt europejski który nigdy nie doczekał się satysfakcjonującej definicji w kategoriach kultury - znalazł się w zagrożeniu wskutek obsesji central bankowców dążących do uratowania euro. Potrzeba będzie pisarza i myśliciela o geniuszu formatu Jeana-Jacques'a Rousseau, by pomóc narodom naszego kontynentu wyjść z tego impasu i zmienić go w szansę znalezienia nowych sposobów myślenia i odmiany serca.

Przełożył Adam Sumera 


\section{Abstract}

\section{Declan Kiberd}

UNIVERSITY OF NOTRE DAME

Home and Away: Ireland, Poland and Others

The migrations into the Celtic Tiger (Ireland during its economic boom) seems to have occurred in two phases. The first (ca. 1996 to 2002) saw incomers who were proud of their culture of origin and curious about the Irish tradition. It was followed by a phase of 'bling' (2002 to the collapse in 2008) characterized by fast money and little cultural interchange. Society in general seemed more superficial and materialistic, and literature failed to embrace the 'Other' as prelude to new fusions. This is surprising, given that many Irish classics - from Swift and Edgeworth to Joyce and McGahern - celebrate the encounter with the 'Other'. Kiberd argues that Irish myths and experiences might still be reconfigured by incomers, even as their cultural narratives are enriched by their encounter with Ireland. The fusion of the various discursive traditions might lead to new forms in literature and culture, as well as a renewal of consciousness.

\section{Keywords}

migration, encounter with the Other, Irishness, globalization 